\title{
Correlations and track analysis for morphoagronomic descriptors in pedigree and parental lines of castor bean
}

\author{
Adielle Rodrigues da Silva ${ }^{{ }^{*}}$ Simone Alves Silva ${ }^{1}$ Vanessa de Oliveira Almeida ${ }^{1}$ \\ Gilmara de Melo Araújo ${ }^{1}$ Carlos Alberto da Silva Ledo ${ }^{2}$
}

${ }^{1}$ Centro de Ciências Agrárias, Ambientais e Biológicas, Universidade Federal do Recôncavo da Bahia (UFRB), 44.380-000, Cruz das Almas, BA, Brasil. E-mail: adi.elle@hotmail.com. *Corresponding author.

${ }^{2}$ Embrapa Mandioca e Fruticultura, Cruz das Almas, BA, Brasil.

ABSTRACT: As castor bean (Ricinus communis L.) reveals immense adaptability to various ecological conditions and due to its socioeconomic significance, new studies have emerged primarily to develop more productive cultivars to suit different regions in Brazil. This study aimed to confirmthe correlations and direct and indirect effects of the morphoagronomic descriptors on castor bean productivity, employing correlation studies and track analysis. Between 2014 and 2015, experiments utilizing the randomized block design were performed, with four replications, which included 208 treatments involving pedigree and parental lines of castor bean, drawn from the germplasm bank of the Universidade Federal do Recôncavo da Bahia. Variables in the correlation analysis included primary racemic insertion, stem diameter, number of stem internodes, plant flowering, plant height, racemic length, number of fruits per raceme, fruit weight per raceme, seed yield per fruit and productivity. Correlations among the variables analyzed were imposed, via track analysis, on the direct and indirect influences of the morphoagronomic descriptors on productivity. The most direct and positively influential descriptors included fruit weight per raceme and number of seeds per raceme; the most direct albeit negatively influential descriptors are the number of internodes on the stem and flowering. Therefore, lines with less number of internodes and requiring fewer days to bloom are more highly productive. These descriptors can thus effectively identify the productive lines. Key words: Ricinus communis L. selection, productivity.

\section{Correlações e análise de trilha para descritores \\ morfoagronômicos em linhagens e parentais de mamoneira}

RESUMO: A capacidade da mamoneira (Ricinus communis L.) em adaptar-se a diferentes condições ecológicas e a sua importância socioeconômica impulsionou novas pesquisas com a espécie, visando o desenvolvimento de cultivares mais produtivas para as diferentes regiões do país. Assim, este trabalho objetivou verificar as correlações e o efeito direto e indireto de descritores morfoagronomicos sobre a produtividade de mamoneiras, por meio do estudo de correlação e análise de trilha. O experimento foi conduzido no período de 2014 a 2015 , em delineamento de blocos casualizados, com quatro repetições. Foram 208 tratamentos compostos por linhagens e parentais de mamoneira do Banco de germoplasma da Universidade Federal do Recôncavo da Bahia. As variáveis utilizadas para a análise de correlação foram: inserção do racemo primário, diâmetro do caule, número de internódios do caule, florescimento da planta, estatura da planta, comprimento do racemo, número de frutos por racemo, peso dos frutos por racemo, rendimento de sementes por fruto e produtividade. As correlações entre as variáveis analisadas foram desdobradas pela análise de trilha, em efeitos diretos e indiretos dos descritores morfoagronomico sobre a produtividade. Os descritores que exercem maiores efeitos diretos no sentido positivo sobre a produtividade são o peso de frutos por racemo e número de sementes por racemo. Os descritores com maior efeito direto no sentido negativo são o número de internódios do caule e o florescimento, indicando que as linhagens com menor número de internódios e que levam menos dias para florescer são mais produtivas. Com isso, estes descritores podem ser eficientes na identificação de linhagens produtivas.

Palavras-chave: Ricinus communis L. seleção, produtividade.

\section{INTRODUCTION}

The castor bean (Ricinus communis L.) is of immense socioeconomical value, because Brazil ranks high among the world's leading castor bean seed producers (FAOSTAT, 2016) and its cultivation generates considerable income and employment opportunity. Its economic value lies chiefly in the oil extracted from seeds which find different uses in the chemical industry for production of paints, varnishes, greases, lubricants, foams and plastics, as well as in the cosmetic field (DOMINGOS et al., 2012). The castor bean polymer has biomedicinal applications for the surgical correction of horses (DORNBUSCH et al., 2010). It is also useful in the production of biodiesel (FURLANETTO \&SANTOS, 2014). Castor bean cake, the main byproduct, is an effective organic fertilizer (SILVA et al., 2012).

Castor bean, grown in the tropical regions, normally has a 250 to 300 - day lifecycle, although it blooms (one bunch) within 50 to 60 days of emergence, as in the case of the 'BRS Paraguaçu' and 'BRS Nordestina' cultivars. Plant produces about five bunches of several orders of castor bean berries, with the prominent bunch representing nearly 
half the production based on the environment and population levels, accounting for an average yield of $1500 \mathrm{~kg} \mathrm{ha}^{-1}$ (AZEVEDO \&BELTRÃO, 2007).

The Instituto Brasileiro de Geografia e Estatística (IBGE, 2015) declared $737 \mathrm{~kg} \mathrm{ha}^{-1}$ as the average national productivity of castor bean in August 2015, which was less than the average output reported by several authors, who recorded yields above $1500 \mathrm{~kg}$ $\mathrm{ha}^{-1}$ in the Planalto Catarinense (VERISSIMO et al., 2009); $1617 \mathrm{~kg} \mathrm{ha}^{-1}$ in the North and Northwest regions of Rio de Janeiro state (BEZERRA NETO et al., 2010); $911 \mathrm{~kg} \mathrm{ha}^{-1}$ in the Londrina region of Paraná (ZORZENONI et al., 2011); And 823kg ha ${ }^{-1}$ in the Bahia Recôncavo (OLIVEIRA et al., 2013). Therefore, this poor national productivity level triggered the quest for assessment and selection techniques focused on raising the performance of this species. However, productivity is not an easily identifiable selection character because it is vastly influenced either directly or indirectly by other descriptors, with respect to the genetic expression of this trait (NOGUEIRA et al., 2012).

Therefore, enhancing the genetic character of castor bean may result in an increased production by developing new cultivars. Genetic improvement of any species focuses on obtaining and distributing castor bean genotypes with higher productivity, and which are early, indiscriminate and/or semi decident. Medium and/ or low, adapted to the mechanical harvest, with high oil content and high level of resistance to the main diseases and pests that occur in the main producing regions of the country (AZEVEDO \& BELTRÃO, 2007).

Correlation analysis; therefore, enhances improved selection efficiency, because the high heritability descriptors closely correlated with productivity can be identified to ensure genetic gains (MOREIRA et al., 2013). However, correlation analysis is limited as it determines only the presence of a relationship among the descriptors, without being able to explain the effects they exert on a specific descriptor (CABRAL et al., 2011).

To appreciate the direct and indirect influences of the descriptors on a principal descriptor, WRIGHT (1921) suggested Track Analysis, a technique of uncovering the correlations. It supports breeders to select the superior genotypes in several crops, including mamoneira including castor bean (PINTO, 2011), sweet potato (MARCHESE, 2010), sunflower (RIGON et al., 2014) and jabuticabeira (SALLA et al., 2015).

However, because of the multicollinearity effect high correlations may negatively influence the regression coefficients which may render the track analysis undependable. This is caused by the interrelationships among the earlier-assessed independent variables (CABRAL et al., 2011).
This research therefore, aimed to explore the correlations among the descriptors and their outcomes via track analysis, in terms of the direct and indirect effects on the productivity of the pedigree and parental lines of castor bean.

\section{MATERIALS AND METHODS}

The experiment was performed in the experimental field in the Centro de Ciências Agrárias, Ambientais e Biológicas (CCABB) of Universidade Federal do Recôncavo da Bahia (UFRB), in the Cruz das Almas municipality, BA, located at $12^{\circ} 40^{\prime} 39^{\prime \prime} S$ latitude, $39^{\circ} 40^{\prime} 23^{\prime \prime}$ at $220 \mathrm{~m}$, with $24.5^{\circ} \mathrm{C}$ temperature on average, $82 \%$ relative humidity, and 1,197mm annual precipitation on average. Based on the classification proposed by Köppen, the climatic conditions are dry and subhumid (type C1), a transition between the Am and Aw zones. A-moderate dystrophic yellow latosol soil is present, sandy loam-clay in texture (EMBRAPA, 1993).

A randomized block experimental design was adopted with four replications including 208 treatments, comprising 203 lines and five parental castor beans taken from the Universidade Federal do Recôncavo da Bahia (UFRB), developed by the Núcleo de Melhoramento Genético e Biotecnologia (NBIO).

In May 2014, the experiment was conducted in a ploughed and harrowed location ready for tillage. Soil correction and fertilization were accomplished at the planting site using a dose of $20 \mathrm{~kg}$ $\mathrm{ha}^{-1}$ of $\mathrm{N}, 80 \mathrm{~kg} \mathrm{ha}^{-1}$ of $\mathrm{P}$ and $40 \mathrm{~kg} \mathrm{ha}^{-1}$ of $\mathrm{K}$. Adopting the $3 \times 1 \mathrm{~m}$ spacing technique, three seeds were sown in each pit. After 25 days of emergence, thinning was performed, leaving only one plant per pit.

The ten morphoagronomic descriptors employed were jointly suggested by the Ministério da Agricultura, Pecuária e Abastecimento, Livestock and Supply - MAPA (BRASIL, 2008) as well as the NBIO, and are mentioned as follows: IRP - Insertion of the primary raceme (Measurement from the soil to the insertion point of the first raceme, in $\mathrm{cm}$ ); DC - stem diameter (measurements were taken in the middle third of the stem, with a digital caliper, in mm); NIC - Number of stem internodes (number of scars seen on the stem in the unit); FLO - Flowering of the plant (number of days from the time of emergence to flowering); EP Plant height (measurement from the soil to the apex of the highest branch of the plant, in $\mathrm{cm}$ ); CR - Length of raceme (mean length of the first four racemes, in $\mathrm{cm}$ ); NFR - Number of fruits per raceme (average number of fruits on the first four racemes); PFR - Fruit weight per raceme (mean fruit weight from the first four racemes, taken with an analytical balance, in g); RSF - 
Seed yield per fruit (percentage of seed weight by fruit weight, in \%) and PROD - Productivity (estimated for each plant in $\mathrm{kg} \mathrm{ha}^{-1}$ ).

The data were submitted to analysis of variance with significance estimated by the $\mathrm{F}$ test at $1 \%$ probability level. The estimated heritability $\left(\mathrm{h}^{2}\right)$, coefficient of genetic variation $(\mathrm{CVg})$, coefficient of environmental variation (CVe) and coefficient of genetic variation ratio were calculated using the GENES program (CRUZ, 2014) by the coefficient of environmental variation $(\mathrm{CVg} / \mathrm{CVe})$. Sequentially, the Pearson correlation coefficients among the descriptors, evaluated by Student $t$ test, were observed.

The correlation matrix was subjected to the multicollinearity test of MONTGOMERY \& PECK (1981) to confirm the degree of multicollinearity. The calculation was based on the condition number (NC), referring to the value obtained by the division between the highest and the lowest eigenvalue of the matrix, in which $\mathrm{NC} \leq 100$ was regarded as weak multicollinearity among the variables, $100<\mathrm{NC}<1000$ as moderate to strong multicollinearity and $\mathrm{NC} \geq 1000$ as severe multicollinearity. Correlation coefficients were categorized as the direct and indirect influence of the independent descriptors (IRP, DC, NIC, FLO, EP, CR, NFR, PFR and RSF) on the dependent descriptor (PROD). Track analysis.

\section{RESULTS AND DISCUSSION}

From the results significant differences were observed between the pedigree and the parent lines for all the descriptors assessed (Table 1). The descriptors RSF, NIC, FLO, IRP, DC, EP and CR revealed coefficients of variation $(\mathrm{CVe} \%)$ below $25 \%$; The NFR, PFR and PROD were in the range of 37.80 to $51.04 \%$.

Coefficient of genetic variation $(\mathrm{CVg})$; however, was in the range of $5.67 \%$ for the RSF to $21.66 \%$ for IRP, implying that the latter descriptor had a higher variability with the potential for direct selection of the superior strains. OLIVEIRA et al. (2010) in a study of genetic correlation among the morphoagronomic descriptors in papaya fruit reported 12.31 to $60.54 \%$ variation for leaf petiole length and the number of commercial fruit, respectively. According to these authors the high CVg values were because of the intra-access variability evaluated.

When the ratio of the genetic variation coefficient to the environmental variation coefficient $(\mathrm{CVg} / \mathrm{CVe})$ rises above or is near to 1 , genetic variability is said to be present, which is a guarantor of success in the germplasm selection, with the potential for new cultivars to be the developed (MARCHESE, 2010).
Thus, from among the descriptors assessed, the ones showing the greatest genetic variation were NIC, with $\mathrm{CVg} / \mathrm{CVe}$ of 1.10 , and IRP, with 0.93 . As a result of the high environmental variation the other descriptors revealed only slight genetic variability, the ratio of $\mathrm{CVg} /$ CVe starting from 0.31 for PROD to 0.65 for FLO.

To accomplish efficient plant breeding a clear understanding of the selection character and heritability coefficient is mandatory, as this also facilitates accurate selection (FALCONER, 1987; ALLARD, 1999; CARVALHO et al., 2008). High heritability descriptors were thus identified as NIC (79.33\%) and IRP (73.35\%), and could find use as selection criteria to make further advancements in the genetic gain. However, caution must be exerted for the low heritability descriptors for selection and more intense breeding techniques, because the environmental effects overlap with the genetic ones in the phenotypic expression.

The descriptor EP, which was an adaptive character and greatly affected by the environment revealed low heritability (34.08\%). PASSOS et al. (2010) reported the heritability for this character as being $28 \%, 47 \%, 69 \%$ and $38 \%$, in the fixed and segregant populations of crosses of different castor bean cultivars. DA SILVA et al. (2011) in their study characterizing the cashew cultivars indicated for cultivation in South Brazil confirmed the heritability for this character as $25 \%$; they indicated that the environmental conditions of temperature, sufficient precipitation and fertilization can support plant growth, whereas the unfavorable conditions could induce losses in this character.

Magnitude, direction and significance must necessarily be observed in a correlation study. The positive coefficient indicates that when one variable increases there is a corresponding increase in the other as well; negative coefficient implies that when one variable increases, there is a corresponding decrease in the other (NOGUEIRA et al., 2012). Thus, correlations between some descriptors may facilitate the selection of superior strains when it becomes difficult to estimate a descriptor of special interest.

In this respect, it was confirmed that barring NIC and RSF, all the remaining descriptors revealed significant correlation with PROD, the descriptor of interest. The highest significant positive correlation values were noted between PROD and PFR, (0.85), and between PROD and EP (0.51). However, the least significant positive correlation value was reportedly between PROD and IRP (0.17); (Table 2).

FURTADO et al. (2014) reported similar results in their study on the yield and the correlation of castor bean and cowpea and sesame 
Table 1 - Summary of variance analysis, heritability estimation $\left(\mathrm{h}^{2}\right)$, coefficient of genetic variation $(\mathrm{CVg})$ and coefficient of genetic variation coefficient by the environmental variation coefficient $(\mathrm{CVg} / \mathrm{CVe})$ for ten morphoagronomic descriptors, evaluated in 203 lines and five parental castor beans from the germplasm bank of UFRB/CCAAB/NBIO. Cruz das Almas-BA, $2014-2015$.

\begin{tabular}{lcccccc}
\hline Descriptors & $\mathrm{QM}$ & $\mathrm{F}$ & $\mathrm{CV}_{\mathrm{e}}(\%)$ & $\mathrm{h}^{2}(\%)$ & $\mathrm{CV}_{\mathrm{g}}(\%)$ & $\mathrm{Reason} \mathrm{CV}_{\mathrm{g}} / \mathrm{CV}_{\mathrm{e}}$ \\
\hline CR & 31.46 & $1.51^{* *}$ & 24.70 & 33.87 & 9.97 & 0.40 \\
NFR & 116.46 & $1.46^{* *}$ & 37.80 & 31.54 & 14.47 & 15.84 \\
PROD & 71105.18 & 1.30 & 51.04 & 23.24 & 0.38 \\
IRP & 729.70 & $3.75^{* *}$ & 23.30 & 73.35 & 21.66 \\
DC & 51.95 & $2.30^{* *}$ & 22.77 & 56.49 & 14.53 & 15.33 \\
NIC & 26.69 & $4.84^{* *}$ & 13.97 & 79.33 & 0.93 \\
FLO & 543.15 & $2.37^{* *}$ & 18.07 & 57.74 & 1.83 \\
EP & 1406.89 & $1.52^{* *}$ & 23.53 & 34.08 & 9.47 & 0.65 \\
RSF & 97.05 & $1.65^{* *}$ & 12.47 & 39.45 & 5.67 & 0.40 \\
PFR & 905.60 & $1.33^{* *}$ & 40.12 & 24.92 & 13.04 \\
\hline
\end{tabular}

${ }^{* *}$ Significant at $1 \%$ probability by F test. CR: Length of raceme; NFR: Number of fruits per raceme; PROD: Productivity; IRP: Insertion of the primary raceme; DC: stem diameter; NIC: Number of internodes on the stem; FLO: Flowering plant; EP: Plant height; RSF: Seed yield per fruit; PFR: Fruit weight per raceme.

in the Paraiba semi-arid; they confirmed a positive and significant correlation of the grain yield in the IAC 2028 and BRS Nordestina cultivars with the number of fruits per raceme $(0.56)$ and raceme lengths (0.61). The longer the racemic length, the greater the number of fruits and the heavier the racemes; thus productivity per plant is favored. With respect to the FLO descriptor, this was the only one showing a significant negative correlation $(-0.45)$ with PROD, thereby implying that as the plant begins to require more number of days to bloom, the productivity gets reduced.

The phenotypic correlation and track analysis showed that it is an effective combination to help assess the manner that a descriptor contributes towards heightening productivity (CABRAL et al., 2011). Thus, despite the evidence of a high correlation between NFR and PFR and also the correlation of PFR with most of the variables, the multicollinearity test pointed that the $\mathrm{NC}$ of the matrix was below 100, implying weak multicollinearity. This was likely because of the greater impact of the variables was indirect, as seen in the trial analysis (Table 3). The track analysis also showed that the descriptors with the most direct but negative effect on productivity were NIC $(-0.22)$, and FLO $(-0.14)$. Thus, these descriptors may enhance and speed-up the

Table 2 - Pearson's correlation coefficient for ten morphoagronomic descriptors, evaluated in 203 strains and five parental lines of castor bean from the germplasm bank of UFRB/CCAAB/NBIO. Cruz das Almas-BA, 2014-2015.

\begin{tabular}{|c|c|c|c|c|c|c|c|c|c|c|}
\hline & $\mathrm{CR}$ & NFR & PROD & IRP & $\mathrm{DC}$ & NIC & FLO & $\mathrm{EP}$ & RSF & PFR \\
\hline $\mathrm{CR}$ & 1 & $0.78^{* *}$ & $0.66^{* *}$ & $0.43^{* *}$ & $0.45^{* *}$ & $0.22^{* *}$ & $-0.00^{\mathrm{ns}}$ & $0.58^{* *}$ & $-0.22^{* *}$ & $0.76^{* *}$ \\
\hline NFR & & 1 & $0.73^{* *}$ & $0.31^{* *}$ & $0.35^{* *}$ & $0.11^{\mathrm{ns}}$ & $-0.06^{\mathrm{ns}}$ & $0.46^{* *}$ & $-0.01^{\mathrm{ns}}$ & $0.81^{* *}$ \\
\hline PROD & & & 1 & 0.17 & $0.29^{* *}$ & $-0.10^{\mathrm{ns}}$ & $-0.35^{* *}$ & $0.51^{* *}$ & $0.07^{\mathrm{ns}}$ & $0.85^{* *}$ \\
\hline IRP & & & & 1 & $0.75^{* *}$ & $0.84^{* *}$ & $0.60^{* *}$ & $0.63^{* *}$ & $-0.47^{* *}$ & $0.32^{* *}$ \\
\hline DC & & & & & 1 & $0.66^{* *}$ & $0.39^{* *}$ & $0.60^{* *}$ & $-0.38^{* *}$ & $0.39^{* *}$ \\
\hline NIC & & & & & & 1 & $0.82^{* *}$ & $0.32^{* *}$ & $-0.56^{* *}$ & $0.12^{\mathrm{ns}}$ \\
\hline FLO & & & & & & & 1 & $0.02^{\text {ns }}$ & $-0.49^{* *}$ & -0.14 \\
\hline EP & & & & & & & & 1 & $-0.25^{* *}$ & $0.52^{* *}$ \\
\hline RSF & & & & & & & & & 1 & $-0.07^{\mathrm{ns}}$ \\
\hline PFR & & & & & & & & & & 1 \\
\hline
\end{tabular}

${ }^{* *}$ Significant at $1 \%$ probability by the $\mathrm{t}$ test; ns not significant. CR: Length of raceme; NFR: Number of fruits per raceme; PROD: Productivity; IRP: Insertion of the primary raceme; DC: Stem diameter; NIC: Number of stem internodes; FLO: Flowering plant; EP: Plant height; RSF: Seed yield per fruit; PFR: Fruit weight per raceme. 
Table 3 - Estimates of the direct and indirect effects of nine descriptors on seed productivity, evaluated in 203 strains and five parental lines of castor bean from the germplasm bank of UFRB/NBIO. Cruz das Almas-BA, 2014-2015.

\begin{tabular}{|c|c|c|c|c|c|c|c|c|c|c|c|}
\hline \multirow{2}{*}{ Descriptors } & \multirow{2}{*}{ Direct effect } & \multicolumn{9}{|c|}{ 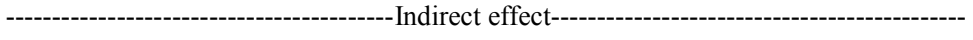 } & \multirow[b]{3}{*}{0.66} \\
\hline & & CR & NFR & IRP & $\mathrm{DC}$ & NIC & FLO & EP & RSF & PFR & \\
\hline CR & -0.03 & & 0.10 & 0.03 & 0.04 & -0.05 & 0.00 & 0.05 & -0.00 & 0.51 & \\
\hline NFR & 0.13 & -0.02 & & 0.02 & 0.03 & -0.02 & 0.01 & 0.04 & -0.00 & 0.54 & 0.73 \\
\hline IRP & 0.08 & -0.01 & 0.04 & & 0.07 & -0.18 & -0.08 & 0.06 & -0.01 & 0.21 & 0.17 \\
\hline DC & 0.09 & -0.01 & 0.05 & 0.02 & & -0.14 & -0.05 & 0.05 & -0.01 & 0.26 & 0.29 \\
\hline NIC & -0.22 & -0.01 & 0.01 & 0.07 & 0.06 & & -0.12 & 0.03 & -0.12 & 0.08 & -0.10 \\
\hline FLO & -0.14 & 0.00 & -0.01 & 0.05 & 0.04 & 0.06 & & 0.00 & -0.01 & -0.09 & -0.35 \\
\hline EP & 0.09 & -0.02 & 0.06 & 0.05 & 0.06 & -0.07 & -0.18 & & -0.00 & 0.34 & 0.51 \\
\hline RSF & 0.02 & 0.01 & -0.00 & -0.04 & -0.03 & 0.12 & 0.07 & -0.00 & & -0.05 & 0.07 \\
\hline PFR & 0.67 & -0.02 & 0.11 & 0.02 & 0.04 & -0.02 & 0.02 & 0.05 & -0.02 & & 0.85 \\
\hline
\end{tabular}

Coefficient of determination $=0.81$. Effect of the residual variable $=0.43$. CR: Length of raceme; NFR: Number of fruits per raceme; IRP: Insertion of the primary raceme; DC: stem diameter; NIC: Number of stem internodes; FLO: Flowering plant; EP: Plant height; RSF: Seed yield per fruit; PFR: Fruit weight per raceme.

choice of superior strains, NIC, in particular, which demonstrated high heritability, $79.33 \%$ (Table 1).

The FLO descriptor was helpful in the indirect selection of prior strains, focusing on the production of castor beans with higher productivity, thus enabling a minimalization of management and production costs, as the strains bloom much faster. The strong direct and positive effect of the PFR (0.67) and NFR (0.13), (refer Table 3) concur with the assessment by the Pearson correlation, indicating a high correlation value between these descriptors and PROD, revealing that the most productive fruits are heavier.

The NIC descriptor exerted no significant effect on simple correlation (Table 2), but revealed a direct albeit negative effect on the selection of the more highly productive strains. This is because of its indirect influence which camouflages its effect on the expression of productivity. Therefore, this descriptor will be very effective in the indirect selection of productive strains, as it is evident prior to seed production.

The descriptors showing the highest positive indirect effects on the PFR included CR (0.51), NFR (0.54) and EP (0.34), thus decreasing the direct influence of these descriptors on PROD. Therefore, the greatest total influence on PROD was PFR (0.85), NFR (0.73), CR (0.66) and EP (0.51). This demonstrated that a principal portion of the effect of these descriptors on productivity arises from the other descriptors.

Thus, all the descriptors assessed, significantly expressed to a large degree the variations in the productivity, which is the descriptor of interest. This is because the coefficient of determination was 0.81 , while the residual effect was 0.43 , indicating that the variations which occurred in the main variable PROD. Were not fully explained by the secondary variables, due to the correlations between the variables being of low magnitude, among which CR $(-0.03)$, NFR (0.13), IRP (0.08), DC (0.09), EP (0.09) and RSF (0.02). In their report PINTO et al., (2011) showed that the research developed with castor bean intercropped with sesame, cotton, maize and cowpea, and analyzed by track analysis, produced a determination coefficient of $99.61 \%$ and residual effect of 0.0621 . This confirmed that the descriptors employed to demonstrate crop productivity were adequate. In their study, TORRES et al. (2015) evaluated the effects of descriptors on the oil content of seven castor bean genotypes and the resultant value of the coefficient of determination was $89.98 \%$.

\section{CONCLUSION}

The two indicators of a strong genetic effect and immense contribution of the heritability are the number of internodes on the stem and the insertion of the primary raceme, which ensure success while selecting the castor bean lines. The number of stem internodes and flowering directly affect the productivity, indicating the potential of these variables. They are useful in the breeding programs as reliable criteria of direct and indirect selection for productivity, as they are easily verifiable and have a high degree of heritability.

\section{ACKNOWLEDGEMENTS}

We thank Petrobrás Biocombustível and the Agência Nacional do Petróleo, Gás Natural e Biocombustíveis (ANP), the Universidade Federal do Recôncavo da Bahia (UFRB) and the 
Coordenação de Aperfeiçoamento de Pessoal de Nível Superior (CAPES) for their support.

\section{REFERENCES}

ALLARD, R.W. Principles of plant breeding. 2.ed. United States of America: John Wiley Professio, 1999. 264p.

AZEVEDO, D. M. P.; BELTRÃO, N. E. M. O Agronegócio da Mamona no Brasil. Brasília: Embrapa Informação Tecnológicas, 2007. 506p.

BEZERRA NETO, F. V. et al. Descritores quantitativos na estimativa da divergência genética entre genótipos de mamoneira utilizando análises multivariadas. Revista Ciência Agronômica, v.41, n.2, p.294-299, 2010. Available from: <http://dx.doi. org/10.1590/S1806-66902010000200018>. Accessed: Nov. 20, 2015. doi: 10.1590/S1806-66902010000200018.

BRASIL. Instruções para execução dos ensaios de distinguibilidade, homogeneidade e estabilidade de cultivares de mamona (Ricinus communis L.). (2008). Diário Oficial da União, n.147, from Aug. 01, 2008. Section 1, p.14-15. Available from: <http://www. agricultura.gov.br/arq_editor/file/vegetal/RegistroAutorizacoes/ Formularios $\% 20$ Prote $\% \mathrm{C} 3 \% \mathrm{~A} 30 \% 20 \mathrm{Cultivares} / \mathrm{MAMONA} \% 20$ FORMULARIO \%2001\%2008\%202008\%20P. Doc>. Accessed: Mar. 04, 2015.

CABRAL, P. D. S. et al. Análise de trilha do rendimento de grãos de feijoeiro (Phaseolus vulgaris L.) e seus components. Revista Ciência Agronômica, v.42, n.1, p.132-138, 2011. Available from: $<$ http://www.ccarevista.ufc.br/seer/index.php/ccarevista/article/ view/1116/518>. Accessed: Oct. 10, 2015.

CARVALHO, F. I. F. et al. Condução de populações no melhoramento genético de plantas. 2.ed. Pelotas: UFPel, 2008. 288p.

CRUZ, C. D. Programa Genes - Aplicativo computacional em genética e estatística, 2014. Available from: <www.ufv.br/dbg/ genes/genes.html>. Accessed: Sept. 27, 2015.

DA SILVA, J. A. G. et al. Caracterização e herdabilidade em caracteres morfológicos e fisiológicos da mamona. Revista Brasileira de Agrociência, v.17, n.3-4, p.348-358, 2011. Available from: <http:// dx.doi.org/10.18539/cast.v17i3.2068>. Accessed: Sept. 15, 2015. doi: 10.18539/cast.v17i3.2068

Empresa Brasileira de Pesquisa Agropecuária. Levantamento detalhado dos solos do Centro Nacional de Pesquisa de Mandioca e Fruticultura Tropical. Cruz das Almas: Embrapa, 1993. 126p.

DOMINGOS, C. A. et al. Biodiesel - Proposta de um combustível alternativo. Revista Brasileira de Gestão e Engenharia, n.5, Paper 09, p.134-178, 2012. Available from: <http://periodicos.cesg.edu.br/ index.php/gestaoeengenharia>. Accessed: Sept. 10, 2015.

DORNBUSCH, P. T. Avaliação radiográfica da aplicação do polímero de mamona em falhas ósseas induzidas em equinos. Archives of Veterinary Science, v.15, n.1, p.01-08, 2010. Available from: $<$ https:// www.researchgate.net/publication/277040063>. Accessed: Aug. 12, 2015. doi: 10.5380 / avs.v15i1.14180.

FALCONER, D. S. Introdução à genética quantitativa. Viçosa: UFV, 1987. 279p.
FAOSTAT (Food and Agriculture Organization of the United Nations Statistics Division). Available from: $<\mathrm{http}$ ://faostat3.fao. org/browse/Q/QC/E>. Accessed: Sept. 13, 2015.

FURLANETTO, E. L.; SANTOS, E. D. Difusão de Inovações Sustentáveis: o caso do biodiesel de mamona no Estado da Paraíba. Teoria e Prática em Administração, v.4, n.1, p.78-103, 2014. Available from: <http://periodicos.ufpb.br/ojs2/index.php/tpa/article/ view/16126/10659>. Accessed: Aug. 02, 2015.

FURTADO, G. F. et al. Rendimento e correlações da mamoneira consorciada com feijão-caupi e gergelim no semiárido paraibano. Revista Brasileira de Engenharia Agrícola e Ambiental, v.18, n.9, p.892-898, 2014. Available from: <http://dx.doi. org/10.1590/1807-1929/agriambi.v18n09p892-898>. Accessed: Oct. 20, 2015. doi: 10.1590/1807-1929/agriambi.v18n09p892-898.

IBGE. Levantamento Sistemático da Produção Agrícola. Available from: $<\mathrm{ftp}$ ///ftp.ibge.gov.br/Producao_Agricola/Levantamento_Sistematico_da Producao_Agricola_[monthly] /Fasciculo/lspa_201508.pdf $>$. Accessed: Sept. 10, 2015.

MARCHESE, A. Seleção de clones de batata-doce resistente a Meloidogyne incognita raça 1. Pesquisa Agropecuária Brasileira, v.45, n.9, p.997-1004, 2010. Available from: <http://dx.doi.org/10.1590/ S0100-204X2010000900009>. Accessed: Oct. 13, 2015. doi: 10.1590/ S0100-204X2010000900009.

MONTGOMERY, D. C.; PECK, E. A. Introduction to linear regression analysis. New York: J. Wiley, 1981. 504p.

MOREIRA, S. O. et al. Correlações e análise de trilha sob multicolinearidade em linhas recombinadas de pimenta (Capsicum annuum L.). Revista Brasileira de Ciências Agrárias, v.8, n.1, p.15-20, 2013. Available from: <http://www.redalyc.org/articulo. oa? id=119025752024>. Accessed: Oct. 06, 2015. doi: 10.5039/ agraria.v8i1a1726.

NOGUEIRA, A. P. O. et al. Análise de trilha e correlações entre caracteres em soja cultivada em duas épocas de semeadura. Bioscience Journal, v.28, n.6, p.877-888, 2012. Available from: $<$ http://www.seer.ufu.br/index.php/biosciencejournal/article/ view/14576/11096>. Accessed: Sept. 12, 2015.

OLIVEIRA, E. J. et al. Correlações genéticas e análise de trilha para número de frutos comerciais por planta em mamoeiro. Pesquisa Agropecuária Brasileira, v.45, n.8, p.855-862, 2010. Available from: $<$ http://dx.doi.org/10.1590/S0100-204X2010000800011>. Accessed: Oct. 06, 2015. doi: 10.1590 / S0100-204X2010000800011.

OLIVEIRA, R. S. et al. Genetic divergence on beaver beanusingthe Ward-mlmstrategy. Revista Ciência Agronômica, v.44, n.3, p.564570, 2013. Available from: <http://dx.doi.org/10.1590/S180666902013000300019>. Accessed: Oct. 16, 2015. doi: 10.1590/S180666902013000300019 .

PASSOS, A. R. et al. Parâmetros genéticos de caracteres agronômicos em genótipos de mamoneira. Pesquisa Agropecuária Brasileira, v.45, n.7, p.709-714, 2010. Available from: <http://dx.doi.org/10.1590/ S0100-204X2010000700011>. Accessed: Sept. 11, 2015. doi: 10.1590 / S0100-204X2010000700011.

PINTO, C. M. et al. Correlações e análise de trilha em mamona consorciada com gergelim, algodão, milho e feijão caupi. Revista Verde, v.6, n.3, p.68-75, 2011. Available from: <http://dx.doi. org/10.18378/rvads.v6i3.674>. Accessed: Sept. 21, 2015. 
RIGON, C. A. G. et al. Correlation and path analysis in the indirect selection of sunflower achene productivity. BioscienceJournal, v.30, suppl.2, p.768-773, 2014. Available from: <http://www.seer. ufu.br/index.php/biosciencejournal/article/view/19835/15237>. Accessed: Sept. 20, 2015.

RODRIGUES, G. B. Análise de trilha de componentes e produção primários e secundários em tomateiro do grupo salada. Pesquisa Agropecuária Brasileira, v.45, n.2, p.155-162, 2010. Available from: $<$ http://dx.doi.org/10.1590/S0100-204X2010000200006>. Accessed: Sept. 21, 2015. doi: 10.1590/S0100-204X2010000200006.

SALLA, V. P. et al. Análise de trilha em caracteres de frutos de jabuticabeira. Pesquisa Agropecuária Brasileira, v.50, n.3, p.218-223, 2015. Available from: <http://www.scielo.br/pdf/pab/ v50n3/0100-204X-pab-50-03-00218.pdf $>$. Accessed: Sept. 21, 2015. doi: 10.1590/S0100-204X2015000300005.

SILVA, S. D. da et al. Uso de torta de mamona como fertilizante orgânico. Pesquisa Agropecuária Tropical, v.42, n.1, p.19-27,
2012. Available from: <https://www.revistas.ufg.br/pat/article/ view/13266/10411>. Accessed: Oct. 13, 2015.

TORRES, F. E. et al. Correlationsand path analysisonoilcontentof castor genotypes. BioscienceJournal, v.31, n.5, p.1363-1369, 2015 Available from: $<$ http://dx.doi.org/10.14393/BJ-v31n5a2015-26391>. Accessed: Sept. 10, 2015. doi: 10.14393/BJ-v31n5a2015-26391.

VERISSIMO, M.A. A. et al. Rendimento de grãos de genótipos de mamona, semeados em três épocas, no Planalto Catarinense. Revista de Ciências Agroveterinárias, v.8, n.2, p.129-138, 2009. Available from: $<\mathrm{http}: / /$ rca.cav udesc.br/rca_2009_2/3Verissimo.pdf $>$. Accessed: Sept. 21, 2015.

WRIGHT, S. Correlation and causation. Journal Agricultural Research, v.20, p.557-585, 1921.

ZORZENONI, T. O. et al. Avaliação das características agronômicas de cultivares de mamona semeadas em Londrina. Nucleus, v.8, n.2, p.143-154, 2011. Available from: $<$ http://dx.doi.org/10.3738/nucleus. v8i2.572>. Accessed: Sept. 17, 2015. doi: 10.3738/nucleus.v8i2.572. 